\title{
Penerapan Metode Example Non Example (ENE) Dalam Pembelajaran Biologi Di Kelas Xii SMA 10 Kota Jambi
}

\author{
Rosana Nasution \\ Sekolah Menengah Atas Negeri 10 Kota Jambi, Indonesia
}

\begin{abstract}
The average percentage of learning results with a value of $\geq 60$ grade XII students MIPA3 and the interest in learning biology in the discussion of the structure and replication of DNA before action is $29.41 \%$ and the remaining interest study by 30\%. It is far from the expected success indicators which is $70 \%$ and interest study at $80 \%$, therefore, it is necessary to take action to improve the outcomes and interest of learning students in grade XII MIPA3. The actions taken on this study used the example non example (EnE) method in the learning activity. The action is carried out in two cycles, wherein at each cycle experienced an increase in the average percentage of learning outcomes with a value of $\geq 60$ that is in the first cycle to 52, 94\% and in the second cycle reaches $73.53 \%$, as well as students ' learning interest increased in the first cycle to be $44.12 \%$ and the second cycle increases significantly $85.29 \%$.
\end{abstract}

Keywords: Learning, learning result, EnE method, structure and replication of DNA

\section{Pendahuluan}

Materi genetik merupakan satu dari bagian topik pembahasan pada mata pelajaran biologi di kelas XII MIPA 3 SMA Negeri 10 Kota Jambi. Materi genetik diberikan pada semester ganjil tahun pelajaran 2019/2020. Fokus pembahasan materi ini terletak pada pertanyaan mengapa setiap orang memiliki sidik jari yang berbeda? Oleh karena itu siswa kelas XII MIPA 3 perlu memahami materi genetik berkenaan dengan Gen, DNA, RNA, Kromosom dan Sintesis protein.

Pada bahasan struktur dan replikasi DNA siswa kela XII MIPA3 sebagian besar mengalami kesulitan untuk memahami dan medeskripsikannya secara tepat. Hal ini terlihat ketika diberikan evaluasi belajar di akhir pembelajaran, dimana rata-rata hasil belajar siswa kelas XII MIPA3 yang memperoleh nilai $\geq 60$ adalah $29,41 \%$ dan minat belajar siswa sebesar 30\%. Rata-rata kelas masih jauh dari persentase harapan yang telah ditetapkan penulis dalam bahasan struktur dan replikasi DNA. Selain itu, ketika penulis menyajikan materi sebagian siswa terlihat kurang paham yang ditandai dengan 
mengulang-ngulang pertanyaan yang sama yang telah disampaikan oleh siswa yang lain dan ketika diberi penjelasan terlihat paham, namun ketika pertanyaan yang sama dilontar kembali oleh penulis, hanya sebagian kecil siswa yang dapat menjelaskan dengan baik. Selanjutnya, ditemui juga sebagian siswa kurang berminat terhadap bahasan struktur dan replikasi DNA yang ditandai dengan tidak memperhatikan dan tidak berperan aktif dalam kegiatan pembelajaran

Berdasarkan permasalahan yang penulis temui, maka penulis melakukan tindakan sebagai upaya meningkatkan rata-rata dan minat belajar kelas XII MIPA 3 pada bahasan struktur dan replika DNA dengan menggunakan metode Example non Example (EnE) dalam proses pembelajaran. Hipotesis dalam tindakan ini adalah ratarata hasil belajar dan minat belajar siswa kelas XII MIPA 3 SMAN 10 Kota Jambi dapat ditingkatkan dengan menerapkan metode EnE.

\section{Tinjauan Pustaka}

\section{Belajar dan Hasil Pembelajaran}

Belajar merupakan perubahan tingkah laku individu sebagai bentuk hasil dari pengalaman terhadap lingkungan sekitarnya. Perubahan perilaku dalam kegiatan belajar melalui serangkaian aktivitas dengan cara membaca, mengamati, mendengar, meniru, memperhatikan, dan lain sebagainya. Kegiatan pembelajaran dipengaruhi oleh beberapa faktor yaitu instrument pembelajaran, lingkungan, dan kondisi siswa. Berikut ini pengertian belajar menurut beberapa ahli yaitu:

1. Perubahan tingkah laku sebagai bentuk interaksi individu dan lingkungannya (Muhammad, 2017);

2. Perubahan tingkah laku yang relative permanen sebagai hasil pengalaman (Siti, 2016);

3. Proses melihat, mengamati, dan memahami sesuatu (Sudjana, 1989).

Hal yang paling utama dalam kegiatan pembelajaran di kelas adalah adanya metode dan strategi pembelajaran yang diaplikasikan seorang guru sesuai dengan tujuan pembelajaran agar hasil dan minat belajar siswa meningkat. 
Hasil belajar menurut Hammalik (2002) adalah perubahan tingkah laku pada diri siswa yang dapat diamati dan diukur dalam bentuk perubahan pengetahuan, sikap dan keterampilan. Hasil belajar adalah bentuk perubahan perilaku yang ada pada individu ke arah positif akibat pengalaman belajar yang dilakukan melalui stimulus dan dorongan yang diberikan. Perubahan perilaku mencakup perubahan pengetahuan, sikap dan keterampilan. Perubahan pengetahuan mengarahkan individu dari yang tidak memiliki pengetahuan akan sesuatu menjadi tahu. Pengetahuan ditunjukkan dengan keterampilan dan sikap siswa yang kritisa terhadap pernyataan atau pertanyaan yang disajikan terkait pengetahuan yang telah dipelajari sebelumnya.

\section{Metode Example non Example (EnE)}

Metode pembelajarn example non example (EnE) merupakan metode pembelajaran denfan menggunakan gambar dan bertujuan untuk mendorong siswa agar berpikir kritis melalui pemecahan masalah yang terdapat dalam gambar (Budiyanto, 2016). Metode ini sejalan dengan prinsip pendidikan pada teori konstruktivisme yaitu guru tidak hanya memberikan pengetahuan kepada siswa tetapi guru juga membantu siswa untuk membangun pengetahuannya melalui pengalaman belajar di sekolah.

Metode ini, dapat diterapkan pada semua kelas yang memiliki karakteristik kemampuan akademik yang tinggi maupun rendah dengan catatan guru dalam melaksanakan metode ini menyesuaikan diri dengan kondisi siswa dalam menggunakan bahasa baik lisan maupun tulisan, berinteraksi dan membuat pertanyaan (Budiyanto, 2016).

Gambar yang digunakan dalam kegiatan pembelajaran dapat disajikan guru dengan menggunakan poster, OHP, infokus, ataupun melalui video yang dibuat oleh guru. Gambar yang dibuat harus jelas dan dapat dilihat siswa dari jarak terjauh posisi siswa duduk di kelas. Selain itu pada pelaksanaan metode ini guru perlu membagi siswa dalam kelompok-kelompok kecil. 
Tujuan penggunaan metode EnE ini adalah untuk memberikan gambaran contoh materi yang dibahas dan gambaran akan sesuatu yang bukanlah contoh dari materi yang dibahas. Langkah-langkah dalam metode EnE adalah sebagai berikut (Budiyanto, 2016):

1. Guru membuat gambar sesuai dengan tujuan pembelajaran;

2. Guru menayangkan gambar melalui infokus;

3. Guru memberikan petunjuk dan kesempatan siswa untuk memperhatikan/ menganalisa gambar;

4. Membentuk grup siswa yang terdiri atas 3 atau 4 siswa untuk melakukan diskusi;

5. Tiap kelompok membacakan hasil diskusi;

6. Guru menjelaskan materi sesuai dengan tujuan yang ingin dicapai;

7. Kesimpulan.

Manfaat dari menggunakan metode EnE adalah siswa menjadi lebih kritis, paham akan konsep dan mampu menganalisa gambar.

Dari uraian tersebut, metode EnE dapat digunakan pada bahasana struktur dan replikasi DNA dengan menampilkan gambar sebagai contoh dari bahasan, dan gambar rumus bangun basa nitrogen dan bukan contoh dari bahasan.

\section{Struktur dan Replikasi DNA}

Struktur dan replikasi DNA merupakan salah satu bahasan pada materi genetik yang membahas tentang susunan kimia inti sel yaitu asam nukleat yang tersusun atas nukleotida-nukleotida sehingga merupakan polinukleotida. Nukleotida terdiri atas satau gula pentosa dan satu basa nitrogen berupa purin atau prieimidin. Basa-basa Nitrogen tersebut terdiri atas lima jenis yaitu adenin (A), guanin (G), sitosin (C), timin (T), dan urasil (U).

DNA terdiri atas emapat basa nitrogen yaitu adenin, guanin, sitosin, dan timin. DNA pada makhluk hidup tersusun atas bahan yang sama yaitu gula deoksiribosa, fosfat dan basa nitrogen. Struktur DNA terdiri atas: 
1. Gula pentose berupa deoksiribosa;

2. Struktur cincin berupa basa nitrogen;

3. Satu, dua, atau tiga gugus fosfat yang terikat pada atom karbon $\mathrm{C} 1$ dan deoksiribosa.

Sehingga molekul, nukleotida yang terdiri atas ikatan gulaa, basa, dan fosfat yang menyusun DNA dapat berbentuk:

1. Adenin nukleotida;

2. Guanin nukleotida;

3. Sitosin nukleotida;

4. Timin nukleotida.

DNA memiliki kemampuan untuk melakukan replikasi dengan melibatkan beberapa enzim yaitu:

1. Helikase yang berfungsi untuk membuka rantai ganda DNA menjadi dua buah rantai tunggal;

2. Polymerase berperan menggabungkan deoksiribonukleosida sebagai unsur penyusun rantai baru;

3. Ligase berfungsi untuk menggabungkan bagian rantai tunggal DNA yang baru terbentuk.

Hipotesis yang digunakan mendeskripsikan replikasi DNA terdiri atas replikasi semikonservatif, konservatif, dan dispersive.

Mengacu pada uraian diatas maka struktur dan replikasi DNA berkaitan dengan unsur basa dan asam yang dijelaskan melalui rantai atau model struktur yang saling berkaitan.

\section{Metode Penelitian}

\section{Setting Penelitian}

Tindakan ini dilakukan di kelas XII MIPA 3 SMA Negeri 10 Kota Jambi pada semester ganjil tahun akademik 2019/2020. Waktu pelaksanaan tindakan adalah di bulan September hingga bulan Oktober 2019, yaitu minggu ke dua bulan September 
2019 untuk tindakan pada siklus pertama, dan minggu ke dua bulan Oktober 2019 untuk tindakan pada siklus ke dua. Penelitian ini bertujuan untuk meningkat rata-rata kelas dan minat siswa kelas XII MIPA3 dalam pokok bahasan struktur dan replikasi DNA dengan menggunakan metode EnE.

\section{Karakteristik Subjek Penelitian}

Siswa kelas XII MIPA3 terdiri atas 34 siswa dengan komposisi siswa perempuan sebanyak 19 orang dan siswa laki-laki 15 orang. Rata-rata siswa kelas XII MIPA 3 memiliki karakteristik kemampuan akademik yang baik dan minat belajar yang baik pula.

\section{Variabel yang Diselidiki}

Hal yang diberi tindakan pada kegiatan ini adalah hasil belajar siswa pada bahasan struktur dan replikasi DNA, dan minat belajar siswa kelas XII MIPA 3 SMA Negeri 10 Kota Jambi.

\section{Rencana Tindakan}

Tindakan yang dilakukan pada penelitian ini dilakukan dengan dua siklus melalui tiga tahapan yaitu tahap perencanaan, pelaksanaan, dan refleksi (Kemmis, Taggart, \& Nixon, 2014). Pada siklus pertama, perencanaan dibuat berdasarkan hasil prasiklus dan disesuaikan dengan metode EnE. Setelah dilakukan tindakan pertama dan merefleksi hasil tindakan. Maka penulis akan melakukan tindakan kedua dengan memperbaiki tindakan yang dilakukan pada siklus kedua.

\section{Teknik Pengumpulan Data}

Data pada penelitian ini dikumpulkan melalui pengamatan, angket, dan dokumen. Pengamatan dilakukan dengan menggunakan lembar observasi. Pada penelitian ini penulis dibantu oleh satu teman sejawat untuk melakukan pengamatan. Angket dilakukan dengan menggunakan pertanyaan tertutup dan terstruktur untuk mendapatkan informasi terkait metode pembelajaran yang digunakan. Sedangkan, dokumentasi yaitu berupa hasil evaluasi awal dan perangkat pembelajaran. 


\section{Indikator Kinerja}

Indikator keberhasilan dalam penelitian ini adalah rata-rata siswa kelas XII MIPA 3 yang memperoleh nilai $\geq 60$ adalah $70 \%$ dan minat belajar siswa meningkat hingga $80 \%$.

\section{Hasil dan Pembahasan}

Hasil dari pelaksanaan tindakan pada bahasan struktur dan replikasi DNA di kelas XII MIPA 3 SMA Negeri 10 Kota Jambi terdiri dari hasil yang dilakukan pada siklus pertama dan siklus kedua. Siswa kelas XII MIPA 3 terdiri atas 34 orang siswa, 19 siswa perempuan dan 15 siswa laki-laki. Uraian hasil persiklus adalah sebagai berikut:

\section{Siklus pertama}

Pada siklus pertama, penulis melakukan tindakan dengan membuat perencanaan tindakan berupa menyediakan gambar rumus bangun basa nitrogen dan model DNA Watson dan Crick dan membagi siswa menjadi 11 kelompok, sepuluh kelompok terdiri atas 3 siswa dan satu kelompok terdiri atas 4 siswa. Setelah melakukan perencanaan pada pelaksanaan kegiatan, penulis mengatur siswa dalam kelas untuk duduk dalamm kelompok masing-masing sesuai dengan hasil penghitungan yang dilakukan oleh siswa. Penulis meminta siswa untuk menghitung mulai dari satu hingga sebelas. Siswa yang menyebut angka satu berada di kelompok satu dan seterusnya. Selanjutnya, penulis menampilkan gambar bangun basa nitrogen dan struktur DNA melalui infokus, kemudian penulis menjelaskan gambar dan memberikan siswa kesempatan untuk memperhatikan gambar tersebut dan menganalisanya dalam kelompok dan mencatatnya untuk didiskusikan bersama.

Pada pelaksanaan kegiatan, teman sejawat dan penulis menggunakan lembar observasi untuk mencatat hasil pengamatan dalam proses belajar tersebut. Sebelum melakuka refleksi, penulis membagikan soal tes untuk dijawab oleh masing-masing siswa sesuai dengan pokok bahasan. Hasil siklus pertama menunjukkan peningkatan rata-rata siswa kelas XII MIPA 3 yang memperoleh hasil belajar $\geq 60$ mencapai 52,94\%, rata-rata siswa kelas XII MIPA3 mengalami peningkatan sebesar 23,53\%. 
Sedangkan, minat siswa mengalami peningkatan hingga 14,12 \%. Tabel. 1 menggambarkan rata-rata kelas dan minat belajar siswa pada materi struktur dan replikasi DNA.

Tabel 1

Persentase Rata-Rata Kelas dan Minat Siswa Kelas XII MIPA 3 pada Siklus Pertama

\begin{tabular}{cclc}
\hline Variabel & $\begin{array}{l}\text { Jumlah siswa } \\
\text { keseluruhan }\end{array}$ & $\begin{array}{l}\text { Jumlah } \\
\text { siswa }\end{array}$ & $\%$ \\
\hline Hasil belajar: & & & \\
a. $\leq 60$ & 34 & 16 & $47,01 \%$ \\
b. $\geq 60$ & & $52,94 \%$ \\
Minat: & 15 & $44,12 \%$ \\
a. Memperhatikan & 15 & $44,12 \%$ \\
b. aktif & & & \\
\hline
\end{tabular}

Pada Tabel. 1 terlihat bahwa pada siklus pertama terjadi peningkatan hasil belajar siswa sebesar $14,71 \%$ dan minat belajar siswa sebesar $44,12 \%$. Selain terjadi peningkatan pada hasil belajar dan minat siswa pada siklus pertama, ditemui juga penambahan waktu belajar agar kegiatan belajar maksimal dan penulis harus dapat memanfaatkan waktu semaksimal mungkin agar waktu belajar yang tersedia selama 3 jam pelajaran dapat dimanfaatkan secara maksimal.

\section{Siklus kedua}

Pada siklus kedua perencanaan kegiatan pembelajaran masih menyesuaikan dengan siklus pertama, namun pada pelaksanaannya pembelajaran penulis dan teman sejawat mempersiapkan kegiatan pembelajaran lebih matang dengan mengkondisikan kelas secara kooperatif melibatkan ketua masing-masing kelompok yang telah dibentuk. Kemudian proses pembelajaran dilanjutkan dengan menampilkan gambar melalui infokus dan meminta siswa untuk mengamati gambar dan menganalisanya dalam kelompok. 
Hasil refleksi menunjukkan bahwa minat siswa kelas XII MIPA 3 pada bahasan struktur dan replikasi DNA semakin meningkat dan hasil belajar rata-rata siswa kelas XII MIPA 3 mencapai indikator keberhasilan yang telah ditetapkan yaitu 70\%. Tabel. 2 menampilkan hasil pelaksanaan siklus kedua.

\section{Tabel 2}

Persentase Rata-Rata Kelas dan Minat Siswa Kelas XII MIPA 3 pada Siklus Kedua

\begin{tabular}{clll}
\hline Variabel & $\begin{array}{l}\text { Jumlah siswa } \\
\text { keseluruhan }\end{array}$ & $\begin{array}{l}\text { Jumlah } \\
\text { siswa }\end{array}$ & $\%$ \\
\hline Hasil belajar: & & & \\
c. $\leq 60$ & 34 & 9 & $26,47 \%$ \\
d. $\geq 60$ & 25 & $73,53 \%$ \\
Minat: & & 29 & $85,29 \%$ \\
c. Memperhatikan & 29 & $85,29 \%$ \\
d. aktif & & & \\
\hline
\end{tabular}

Tabel. 2 menginformasikan peningkatan persentase rata-rata hasil belajar siswa $\geq 60$ sebanyak 19,59\%. Rata-rata hasil belajar siswa kelas XII MIPA3 telah mencapai indikator keberhasilan yang ditetapkan oleh penulis yaitu 70\%. Minat belajar siswa kelas XII MIPA3 terhadapat bahasan struktur dan replikasi meningkat sangat signifikan dari 44,12 \% menjadi $85,29 \%$. Perbandingan pencapaian rata-rata hasil belajar siswa kelas XII MIPA 3 dan minat belajar dari prasiklus sampai siklus kedua digambarkan pada Gambar. 1 sebagai berikut: 


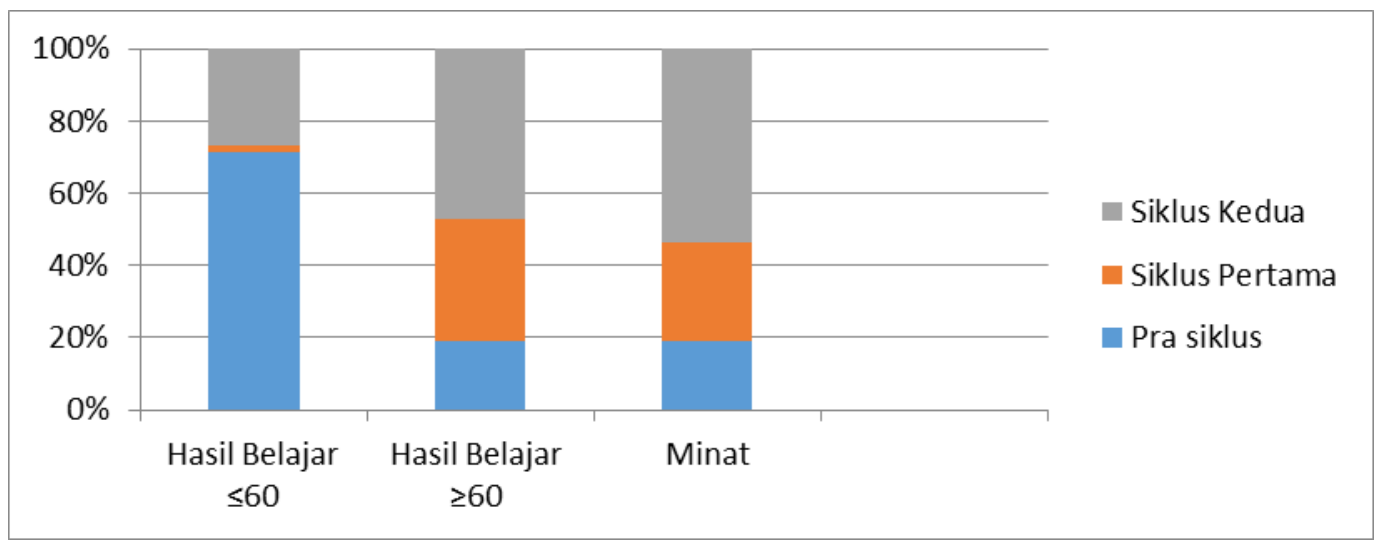

Gambar 1 Perbandingan Rata-Rata Hasil Belajar dan Minat Siswa Kelas XII MIPA3

Pelaksanaan tindakan sebagai upaya meningkatkan rata-rata hasil belajar siswa dan minat belajar siswa kelas XII MIPA 3 pada bahasan struktur dan replikasi DNA dengan menggunakan metode EnE menunjukkan peningkatan. Hal ini sesuai dengan tujuan dari penggunaan metode EnE dalam pembelajaran yaitu pembelajaran dengan menggunakan gambar dan memberikan kesempatan kepada siswa untuk lebih leluasa, mandiri, dan belajar menyenangkan untuk memahami materi struktur dan replikasi DNA. Pada saat menggunakan metode EnE penulis menyusun gambar yang dapat dianalisa dengan baik oleh siswa (Budiyanto, 2016). Gambar-gambar yang dirancang berasal dari sumber lain yang disajikan melalui infokus agar lebih menarik.

Dalam menerapkan metode ini, penulis harus lebih disiplin pada perencanaan kegiatan pembelajaran yang telah ditetapkan agar waktu pembelajaran yang disediakan dapat digunakan semaksimalkan mungkin, karena jika penulis mengindahkan perencanaan yang telah ditetapkan maka waktu kegiatan pada waktu yang telah tersedia tidka cukup. Oleh karena itu penggunaan metode EnE dapat diterapkan dalam bahasan struktur dan replikasi DNA jika disiplin waktu yang telah ditetapkan dijalankan secara tepat. 


\section{Kesimpulan}

Berdasarkan hasil dan pembahasan maka penggunaan metode EnE dalam pembelajaran biologi dapat meningkatkan hasil belajar dan minat siswa. Disarankan, penggunaan metode ini diikuti dengan disiplin waktu dan membagi siswa dalam kelompok dengan kemampuan anggota kelompok yang berimbang.

\section{Daftar Rujukan}

Budiyanto, A.K. 2016. Sintaks 45 metode pembelajaran dalam students centered learning (SCL). Malang: Univ. Muhammadiyah alang Press.

Hammalik, O. 2002. Psikologi belajar dan mengajar. Bandung: Sinarbaru.

Hudojo. 2013. Strategi Pembelajaran. Jakarta: Depdikbud.

Kemmis, S., Taggart, R., \& Nixon, R. 2014. The action research planner: Doing critical participatory action research. Singapore: Springer.

Muhammad, D. D. 2017. Belajar dan Pembelajaran. Jurnal kajian ilmu-ilmu keislaman, Vol.3 No.2.

Nurdyansyah, \& Fahyuni, F. E. 2016. Inovasi model pembelajaran: versi kurikulum 2013. Sidoarjo: Nizamia Learning Center.

Nurhayati, N., \& Wijayanti. R. 2017. Biologi. Bandung: Erlangga.

Siti, N. 2016. Minat Belajar sebagai determinan hasil belajar siswa. Jurnal pendidikan manajemen perkantoran, Vol.1 No. 1.

Sudirman, A. 2001. Interaksi dan motivasi belajar mengajar. Jakarta: Pt. Raja Grafindo Persada. 
Rosana Nasution 